\title{
A survey of frailty services in acute NHS hospitals in the West Midlands
}

\section{Introduction}

An increasing percentage of acute medical admissions are of patients with at least one frailty syndrome. ${ }^{1}$ Frailty is associated with poorer hospital outcomes. ${ }^{2}$ Managing the complex, multidisciplinary needs of frail patients is an increasing challenge. ${ }^{1}$ Recently there has been a move towards creating dedicated frailty services, designed to identify frail patients early in order to improve outcomes. There is currently no 'gold standard' for frailty services. They are usually set up at a local level, leading to a significant variation in the design.

The NHS Benchmarking Network revealed that $40 \%$ of trusts have a dedicated geriatric team based in the emergency department and $52 \%$ had a specialist frailty unit. ${ }^{3}$ This survey was designed to establish the current services available in the acute hospitals across the West Midlands.

\section{Method}

A survey was created using Survey Monkey consisting of 10 questions (Table 1) and distributed electronically to all elderly care registrars in a training post in the West Midlands.

\section{Results}

We received responses from 14 out of 18 hospitals. Only one hospital had no frailty service.

Of the 14 , nine had frailty wards. Of these, three reported they had clear admission criteria. There was a wide variation in who applied these criteria within working hours; bed manager, ward manager, ward sister, geriatric specialist doctor and emergency department co-ordinator having one response each. This variation was seen less out of hours when the decision was made by the bed manager (four responses), emergency department co-ordinator (three responses) or ward manager (one response).

There was a range in the number of perceived inappropriate admissions both in hours and outside of them. Five hospitals reported inappropriate admissions occurring at least once a week in hours. Five hospitals reported daily inappropriate admissions out of hours. Only one hospital reported never receiving inappropriate admissions.

Eleven of the hospitals had a frailty service working with the emergency department. Eight of these were run by geriatric consultants, the others being primarily led by therapy teams.

\section{Discussion}

Frailty services are now commonplace in hospitals within the West Midlands with the majority of hospitals providing a frailty ward

\begin{tabular}{|c|c|}
\hline \multicolumn{2}{|l|}{$\begin{array}{l}\text { Which hospital do you } \\
\text { work at? }\end{array}$} \\
\hline $\begin{array}{l}\text { Does your hospital have a } \\
\text { frailty / acute geriatric ward? }\end{array}$ & Yes \\
\hline $\begin{array}{l}\text { Are there clear criteria } \\
\text { for suitable patients for } \\
\text { admission to this ward? }\end{array}$ & Yes \\
\hline If so, what are the criteria? & \\
\hline $\begin{array}{l}\text { In working hours who } \\
\text { applies these criteria / } \\
\text { decides on admissions to } \\
\text { the ward? }\end{array}$ & $\begin{array}{l}\text { Bed manager } \\
\text { Ward manager } \\
\text { Geriatric consultant/SpR } \\
\text { On-call medical SpR } \\
\text { A\&E/AMU coordinator } \\
\text { Other (please specify) }\end{array}$ \\
\hline $\begin{array}{l}\text { Out of hours who applies } \\
\text { these criteria / decides on } \\
\text { admissions to the ward? }\end{array}$ & $\begin{array}{l}\text { Bed manager } \\
\text { Ward manager } \\
\text { Geriatric consultant/SpR } \\
\text { On-call medical SpR } \\
\text { A\&E/AMU coordinator } \\
\text { Other (please specify) }\end{array}$ \\
\hline $\begin{array}{l}\text { How frequently are there } \\
\text { inappropriate admissions } \\
\text { to the ward in normal } \\
\text { working hours? }\end{array}$ & $\begin{array}{l}\text { Daily } \\
1-2 \text { times a week } \\
\text { Weekly } \\
\text { Monthly } \\
\text { Very rarely/less than once a month } \\
\text { Never }\end{array}$ \\
\hline $\begin{array}{l}\text { How frequently are there } \\
\text { inappropriate admissions } \\
\text { to the ward out of hours? }\end{array}$ & $\begin{array}{l}\text { Daily } \\
1-2 \text { times a week } \\
\text { Weekly } \\
\text { Monthly } \\
\text { Very rarely/less than once a month } \\
\text { Never }\end{array}$ \\
\hline $\begin{array}{l}\text { Does your hospital have a } \\
\text { frailty service based in ED/ } \\
\text { AMU? }\end{array}$ & Yes \\
\hline Who leads this service? & $\begin{array}{l}\text { Geriatric consultants } \\
\text { Geriatric registrars } \\
\text { Specialist nurses/ANPs } \\
\text { Non-geriatric consultant } \\
\text { Other (please specify) }\end{array}$ \\
\hline
\end{tabular}

$\mathrm{A} \& \mathrm{E}$ = emergency department; $\mathrm{AMU}$ = acute medical unit; ANPs = advanced nurse practitioner; $E D$ = emergency department; $\mathrm{SpR}=$ specialty registrar. 
$(60 \%)$ as well as a frailty service working with the emergency department (73\%), which are higher than the reported national averages of $52 \%$ and $40 \%$, respectively.

Inappropriate admissions to the unit are a problem affecting nearly all hospitals and occur more frequently outside of working hours. This may be due to unclear or absent admissions criteria as well as the fact that individuals making admission decisions out of hours tend not to be involved in individual patient's care but the management of the hospital as a whole.

\section{Conclusion}

This survey of services in the region confirms that nearly all hospitals in the region are providing frailty services. Further research is necessary to establish whether the reported absence of admission criteria is due to lack of knowledge among elderly care registrars of existing criteria or a lack of criteria itself. Perceived inappropriate admissions are a problem across the region especially out of hours. This may be reduced with clearer admission criteria for these specialist units.
HOLLY JACQUES

Specialty registrar 5 in geriatric medicine and clinical teaching fellow, Warwick Hospital, Warwick, UK

JAMES GAYWOOD

Specialty registrar 5 in geriatric medicine and clinical teaching fellow, Warwick Hospital, Warwick, UK

KANWALJIT SINGH

Geriatric consultant, Good Hope Hospital, Sutton Coldfield, UK

\section{References}

1 Soong J, Poots AJ, Scott S et al. Quantifying the prevalence of frailty in English hospitals. BMJ Open 2015;5:e008456.

2 Wallis S], Wall J, Biram RW, Romero-Ortuno R. Association of the clinical frailty scale with hospital outcomes. QJM 2015;108:943-9.

3 NHS Benchmarking Network. Older people's care in acute settings national report. NHS Benchmarking Network, 2017.

Address for correspondence: Dr Holly Jacques, Warwick Hospital, Lakin Road, Warwick CV34 5BW, UK.

Email: jacquesholly1@gmail.com

\section{Royal College} of Physicians

\section{Consent and confidentiality in genomic medicine}

\section{Genetic or genomic tests are increasingly used in everyday medical practice. Every clinical field will encounter such tests to a greater or lesser extent.}

\begin{abstract}
Published in 2019, this third edition by the Joint Committee on Genomics in Medicine provides updated guidance on the use of genetic and genomic information in the clinic. Health professionals from all areas of medicine need to know and understand how consent and confidentiality issues may arise, and to understand the potential ways in which the use of genomic tests may change the nature of the relationship between healthcare professionals and patients.
\end{abstract}

Download the guidance at:

www.rcplondon.ac.uk/consent-confidentiality-genomic-medicine

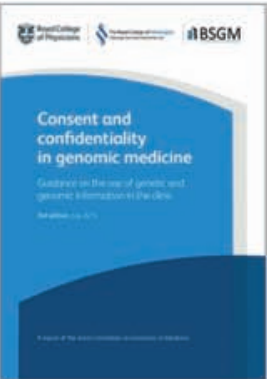

